\begin{tabular}{r|l|l|l}
$\begin{array}{c}\text { Case Reports in } \\
\text { Gastroenterology }\end{array}$ & $\begin{array}{l}\text { Case Rep Gastroenterol 2010;4:502-509 } \\
\text { DOl: 10.1159/000322693 }\end{array}$ & $\begin{array}{l}\text { Published online: } \\
\text { November 23, 2010 }\end{array}$ & $\begin{array}{l}\text { O 2010 S. Karger AG, Basel } \\
\text { ISSN 1662-0631 } \\
\text { www.karger.com/crg }\end{array}$ \\
\hline
\end{tabular}

This is an Open Access article licensed under the terms of the Creative Commons AttributionNonCommercial-NoDerivs 3.0 License (www.karger.com/OA-license), applicable to the online version of the article only. Distribution for non-commercial purposes only.

\title{
A Case of Autoimmune Hepatitis Treated with Rituximab
}

\author{
E. Barth J. Clawson \\ United States Air Force, Lackland AFB, San Antonio, Tex., USA
}

\section{Key Words}

Autoimmune $\cdot$ Hepatitis $\cdot$ Rituximab

\begin{abstract}
Autoimmune hepatitis (AIH) is a form of chronic hepatitis of unknown etiology. It was first described in the 1950s as a form of chronic hepatitis noted in younger women. It was later termed lupoid hepatitis due to its association with autoantibodies before being named AlH in 1965. Corticosteroids and azathioprine have been the standard therapy for $\mathrm{AlH}$, but due to treatment failures and toxicities from these medications, new medications are being investigated as possible treatment options. Rituximab has been used in various autoimmune disorders with good success. We report the case of a 34-year-old Caucasian woman with a history of B cell lymphoma and concurrent $\mathrm{AlH}$ treated with rituximab. The diagnosis of AlH was made by classic serological and histological features. The patient was initially treated with steroids but had a progression of her disease as well as suffering toxicities from the steroids. She was then given eight weeks of rituximab with good improvement in both laboratory and histological findings.
\end{abstract}

\section{Introduction}

Autoimmune hepatitis (AIH) is a form of chronic hepatitis that can lead to end-stage liver disease and cirrhosis if left untreated. AIH was first described in the 1950s by Waldenstrom [1] and since that time much research has been done to better understand the pathogenesis of the disease [2]. The presence of autoantibodies and elevated levels of immunoglobulins found in AIH point toward an autoimmune etiology, as does its response to immunosuppresants [3]. The mainstay of treatment has been with corticosteroids and azathioprine [4]. Treatment failures with standard regimens have been quoted to occur in at least $9 \%$ of treated patients [5]. Treatment failures are usually treated by the administration of high-dose steroids with or without azathioprine with the risk of increased toxicities [5]. Several other medications have been tried with varying degrees of success, including myophenil and tacrolimus [5]. Rituximab is a potential 


\begin{tabular}{r|l|l|l}
$\begin{array}{c}\text { Case Reports in } \\
\text { Gastruanteriology }\end{array}$ & $\begin{array}{l}\text { Case Rep Gastroenterol 2010;4:502-509 } \\
\text { DOI: 10.1159/000322693 }\end{array}$ & $\begin{array}{l}\text { Published online: } \\
\text { November 23, 2010 }\end{array}$ & $\begin{array}{l}\text { O 2010 S. Karger AG, Basel } \\
\text { ISSN 1662-0631 } \\
\text { www.karger.com/crg }\end{array}$ \\
\hline
\end{tabular}

treatment option in those who have failed conventional treatment or who cannot tolerate current treatment strategies. Rituximab functions as a chimeric monoclonal antibody against the CD20 protein which is found primarily on the surface of B lymphocytes. Rituximab induces $B$ cell depletion and thus suppresses the production of pathogenic antibodies. Rituximab has a relatively favorable side effect profile and may become a new treatment option in AIH.

\section{Case Report}

A 27-year-old female was in her usual state of health when she presented to her primary care physician with complaints of left postauricular pain for about one month duration. Review of symptoms was positive for fevers, chills, fatigue, night sweats and abdominal pain. Her past medical history included primary biliary cirrhosis, migraine headaches, gastric esophageal reflux disease and endometriosis. Social history did not reveal any alcohol use. Her medications included ursodiol $300 \mathrm{mg}$ three times a day, atarax $25 \mathrm{mg}$ three times a day, and nexium $40 \mathrm{mg}$ every day. Her family history was significant for a sister with systemic lupus erythematosus and an aunt with systemic lupus erythematosus and scleroderma. Physical exam revealed normal vital signs, with a $0.5 \times 0.5 \mathrm{~cm}$ nontender immobile lymph node in the right posterior auricular area and a $2 \times 2 \mathrm{~cm}$ nontender immobile lymph node in the left posterior auricular area. Abdominal examination revealed hepatomegaly and right upper quadrant tenderness. No other lymphadenopathy was appreciated. Laboratory data revealed alanine aminotransferase (ALT) $92 \mathrm{IU} / \mathrm{l}$, aspartate aminotransferase (AST) $81 \mathrm{IU} / \mathrm{l}$, alkaline phosphatase $387 \mathrm{IU} / \mathrm{l}$ and total bilirubin $0.3 \mathrm{mg} / \mathrm{dl}$. Her previous aminotransferases had been normal. The left lymph node was biopsied and the pathology report revealed a marginal B cell lymphoma with the majority of lymphocytes immunoreactive to CD20. Further staging was done, including contrast-enhanced computed tomography scans of the abdomen/pelvis and chest, positron emission tomography and a bone marrow biopsy and no other sites of disease were found. The patient was given a diagnosis of stage $2 \mathrm{~b}$ marginal zone $\mathrm{B}$ cell lymphoma. At that time, the tumor board met to discuss the patient's plan of care. There was some concern about initiating chemotherapy given her young age and fear of toxicities and it was decided to first evaluate her liver disease before recommending any further therapy.

She was then seen by a hepatologist for her elevated aminotransferases as well as for her continued abdominal pain. It was decided to proceed with a liver biopsy. Biopsy revealed interface and lobular hepatitis with an abundance of plasma cells and stage 2 fibrosis as well as a large granuloma centered on a bile duct. In addition, her antinuclear antibody (ANA) titer was noted to be positive at 1:640. Anti smooth muscle antibodies (ASMA) and anti liver-kidney microsomal antibodies (ALK) were checked and were negative. Her immunoglobulin $\mathrm{G}(\mathrm{IgG})$ level was noted to be 2,320 mg/dl. Laboratory tests for hepatitis $B$ virus antigen and anti hepatitis $C$ virus antibody were negative. Abdominal ultrasonography revealed a liver of normal size and echogenicity. She was given the diagnosis of AIH with overlap primary biliary cirrhosis and was started on prednisone $30 \mathrm{mg}$ a day with a planned taper. Her symptoms and aminotransferases improved slightly but several months later she had an increase in abdominal pain and fatigue and it was noted on laboratory examination that her aminotransferases had again increased. She had also gained 21 pounds since being started on prednisone. She then had a repeat liver biopsy which showed worsening of her hepatic fibrosis. At this time, there was concern that the patient was not tolerating steroids well and was having progression of her liver disease. Her physicians were concerned about attempting treatment with immunosuppressants such as azathioprine given her history of B cell lymphoma. It was then decided to start her on weekly therapy of rituximab to address both her B cell lymphoma and her AIH. She was given eight weekly infusions of rituximab $375 \mathrm{mg} / \mathrm{m}^{2}$. During the course of this treatment, her physicians were able to taper down her steroids to $7 \mathrm{mg}$ a day. After this treatment course, her abdominal pain and fatigue resolved and her laboratory exams revealed AST $31 \mathrm{IU} / \mathrm{l}$, ALT $55 \mathrm{IU} / \mathrm{l}$, alkaline phosphatase $186 \mathrm{IU} / \mathrm{l}$, and total bilirubin $0.5 \mathrm{mg} / \mathrm{dl}$. Her lymphadenopathy completely resolved.

The patient did well until several months later when she began to again have right upper quadrant abdominal pain as well as an increase in her aminotransferases: AST 49 IU/l, ALT 82 IU/l. At that time quantitative immunoglobulin level was checked and revealed an IgG level of 1,562 $\mathrm{mg} / \mathrm{dl}$. It was decided to treat her with another four weeks of rituximab therapy. After this, her aminotransferases normalized, her IgG level decreased and her symptoms resolved and she was able to be weaned off her steroids 


\begin{tabular}{r|l|l|l} 
Case Reports in & $\begin{array}{l}\text { Case Rep Gastroenterol 2010;4:502-509 } \\
\text { DOl: 10.1159/000322693 }\end{array}$ & $\begin{array}{l}\text { Published online: } \\
\text { November 23, 2010 }\end{array}$ & $\begin{array}{l}\odot \text { ISSN 1662-0631 } \\
\text { www.karger.com/crg }\end{array}$ \\
\hline
\end{tabular}

completely. Repeat liver biopsy revealed mild chronic inflammation with no significant number of plasma cells and no interface hepatitis. There was only mild portal fibrosis present.

At follow-up six years later, the patient remained stable with normal aminotransferase levels, and a repeat liver biopsy revealed quiescent disease with minimal chronic inflammation and no interface hepatitis. Her B cell lymphoma remains in remission since her first rituximab treatment.

\section{Discussion}

AIH is a form of chronic hepatitis of unknown cause that can lead to end-stage liver disease and cirrhosis if left untreated. Its association with circulating antibodies and elevated immunoglobulins supports an autoimmune etiology. It was first described in the 1950s and since that time much research has been done to better understand the etiology and natural history of the disease. An accepted hypothesis of the pathogenesis of AIH is that there exists a genetic predisposition and that this combined with an unknown environmental trigger leads to a cell-mediated attack on certain liver antigens [6]. There appears to be an abnormal expression of class II human leukocyte antigens on the antigen-presenting cells presented to helper $T$ cells [6]. It is believed this aberrant human leukocyte antigens display is a result of an infection or of an exposure to an unknown environmental trigger. There is a paucity of epidemiologic data available on AIH but one recent study from New Zealand revealed age-standardized incidence and prevalence to be 1.7 and 18.9 per 100,000, respectively. The authors also noted a higher prevalence in Caucasians and the majority of cases presented after 40 years of age [7], although AIH does occur in children and young adults. As with most autoimmune diseases, there is a higher female predominance [7]. To help diagnose AIH, a diagnostic scoring system was composed by an international panel initially in 1993 and revised in 1999 (table 1) [8], which includes histological and serological findings, the presence of autoantibodies and exclusion of other causes of hepatitis [8].

Patients typically present with nonspecific symptoms that may include abdominal pain, nausea, jaundice and fatigue. There is much variability in disease presentation, and patients may be asymptomatic or present with fulminant hepatic failure [9]. The disease has characteristic histological findings of a chronic mononuclear infiltrate typically involving the limiting plate (interface hepatitis) usually with a rich plasma cell infiltrate, and AIH is also associated with lobular hepatitis (fig. 1, fig. 2) [10]. Lab work tends to reveal elevations in aminotransferases more so than abnormalities in bilirubin and alkaline phosphotase [3]. AIH is also associated with elevated levels of serum globulins, particularly IgG, which are generally 1.2 to 3 times the normal level [3]. In addition, AIH is associated with the presence of autoantibodies, including ANA, ASMA, ALK, perinuclear anti-neutrophil cytoplasmic antibodies, and anti liver cytosol type 1 antibodies (anti-LC1) [8, 11].

Two types of AIH have been identified and classified as type 1 and 2. Type 1 accounts for roughly $80 \%$ of cases and tends to have positive serology for ANA, ASMA or both [12]. Type 2 is less common and characterized by ALK or anti-LC1 antibodies. In addition to the differences in serological findings, type $2 \mathrm{AIH}$ also seems to affect younger adults and children and to have more treatment failures [13].

Two well-established treatment regimens are effective in AIH [14] which include either prednisone alone or prednisone in combination with azathioprine. Ongoing research is 


\begin{tabular}{r|l|l|l}
$\begin{array}{r}\text { Case Reports in } \\
\text { Gastruenterology }\end{array}$ & $\begin{array}{l}\text { Case Rep Gastroenterol 2010;4:502-509 } \\
\text { DOI: 10.1159/000322693 }\end{array}$ & $\begin{array}{l}\text { Published online: } \\
\text { November 23, 2010 }\end{array}$ & $\begin{array}{l}\text { O 2010 S. Karger AG, Basel } \\
\text { ISSN 1662-0631 } \\
\text { www.karger.com/crg }\end{array}$ \\
\hline
\end{tabular}

being conducted to try and identify patient features that may lead to treatment failure, which occurs at least $9 \%$ of the time [5]. Other medications have been investigated for treatment failures, including tacrolimus, cyclophosphamide, ursodeoxycholic acid and mycophenolate mofetil [15], with varying degrees of success.

Rituximab is an interesting therapeutic option for $\mathrm{AIH}$ as it works primarily on the humoral immune response by inducing $B$ lymphocyte depletion and decreased production of autoantibodies. AIH is known to involve more of a cell-mediated immune process, but rituximab has been used successfully in other diseases which are believed to involve a primarily cell-mediated process, including multiple sclerosis [16]. It is believed that rituximab works in these situations by indirectly altering cell-mediated responses. Mouse models have shown that B lymphocyte depletion impairs CD4+ T cell activation in response to pathogen challenges, which may in part explain how rituximab is effective in primarily cell-mediated disease processes, including AIH [16].

Rituximab has a relatively favorable side effect profile and thus may be a good option for treatment failures and perhaps even initial management of AIH in individual cases where patients are poor candidates for steroids and azathioprine. More studies are needed to investigate this further.

\section{Conclusion}

Our patient presented with concurrent diagnoses of B cell lymphoma and AIH. She was initially treated with steroids for her AIH but was intolerant to the side effects and also showed progression of her liver disease. Due to her history of B cell lymphoma, it was then decided to pursue treatment with rituximab. After receiving treatment with rituximab the patient achieved both clinical and histological remission. Further studies need to be performed to further elicit the role of rituximab in $\mathrm{AIH}$. 


\begin{tabular}{|c|c|c|c|}
\hline $\begin{array}{l}\text { Case Reports in } \\
\text { astuenteroloos }\end{array}$ & $\begin{array}{l}\text { Case Rep Gastroenterol 2010;4:502-509 } \\
\text { DOI: } 10.1159 / 000322693\end{array}$ & $\begin{array}{l}\text { Published online: } \\
\text { November 23, } 2010\end{array}$ & $\begin{array}{l}\text { (c) } 2010 \text { S. Karger AG, Basel } \\
\text { ISSN } 1662-0631 \\
\text { www.karger.com/crg }\end{array}$ \\
\hline
\end{tabular}

Table 1. Scoring system for the diagnosis of AIH [8]

\begin{tabular}{|c|c|c|}
\hline Category & Factor & Score \\
\hline Gender & female & +2 \\
\hline \multirow{2}{*}{ Alk phos: AST (or ALT) ratio } & $>3$ & -2 \\
\hline & $<1.5$ & +2 \\
\hline$\gamma$-Globulin or IgG (times above upper & $>2.0$ & +3 \\
\hline \multirow[t]{3}{*}{ limit of normal) } & $1.5-2.0$ & +2 \\
\hline & $1.0-1.5$ & +1 \\
\hline & $<1.0$ & 0 \\
\hline \multirow[t]{4}{*}{ ANA, SMA, or anti-LKM1 titers } & $>1: 80$ & +3 \\
\hline & $1: 80$ & +2 \\
\hline & $1: 40$ & +1 \\
\hline & $<1: 40$ & 0 \\
\hline$\overline{\mathrm{AMA}}$ & positive & -4 \\
\hline \multirow[t]{2}{*}{ Viral markers of active infection } & positive & -3 \\
\hline & negative & +3 \\
\hline \multirow[t]{2}{*}{ Hepatotoxic drugs } & yes & -4 \\
\hline & no & +1 \\
\hline \multirow{2}{*}{ Alcohol } & $<25 \mathrm{~g} / \mathrm{d}$ & +2 \\
\hline & $>60 \mathrm{~g} / \mathrm{d}$ & -2 \\
\hline Concurrent immune disease & any nonhepatic disease of an immune nature & +2 \\
\hline Other autoantibodies $^{\mathrm{a}}$ & anti-SLA/LP, actin, LC1, pANCA & +2 \\
\hline \multirow[t]{6}{*}{ Histologic features } & interface hepatitis & +3 \\
\hline & plasma cells & +1 \\
\hline & rosettes & +1 \\
\hline & none of above & -5 \\
\hline & biliary changes ${ }^{\mathrm{b}}$ & -3 \\
\hline & atypical features ${ }^{c}$ & -3 \\
\hline HLA & DR3 or DR4 & +1 \\
\hline \multirow[t]{2}{*}{ Treatment response } & remission alone & +2 \\
\hline & remission with relapse & +3 \\
\hline \multicolumn{3}{|l|}{ Pretreatment score } \\
\hline Definite diagnosis & & $>15$ \\
\hline Probable diagnosis & & $10-15$ \\
\hline \multicolumn{3}{|l|}{ Posttreatment score } \\
\hline Definite diagnosis & & $>17$ \\
\hline Probable diagnosis & & $12-17$ \\
\hline
\end{tabular}

Alk phos = serum alkaline phosphatase level; ALT = serum alanine aminotransferase level; AMA = antimitochondrial antibodies; ANA = antinuclear antibodies; AST = serum aspartate aminotransferase level; HLA = human leukocyte antigen; IgG = serum immunoglobulin G level; anti-LKM1 = antibodies to liver/kidney microsome type 1; SMA = smooth muscle antibodies; HLA-DR3, DR4 = human leukocyte antigen-D.

${ }^{a}$ Unconventional or generally unavailable antibodies associated with liver disease include perinuclear antineutrophil cytoplasmic antibodies (pANCA) and antibodies to actin, soluble liver antigen/liver pancreas (anti-SLA/LP), asialoglycoprotein receptor, and liver cytosol type 1 (LC1).

bIncludes destructive cholangitis, nondestructive cholangitis, or ductopenia.

'Includes steatosis, iron overload consistent with genetic hemochromatosis, alcoholic hepatitis, viral features (ground-glass hepatocytes), or inclusions (cytomegalovirus, herpes simplex).

Data from [17]. 


\begin{tabular}{l|l|l|l}
$\begin{array}{r}\text { Case Reports in } \\
\text { Gastruenterology }\end{array}$ & $\begin{array}{l}\text { Case Rep Gastroenterol 2010;4:502-509 } \\
\text { DOI: 10.1159/000322693 }\end{array}$ & $\begin{array}{l}\text { Published online: } \\
\text { November 23, 2010 }\end{array}$ & $\begin{array}{l}\text { O 2010 S. Karger AG, Basel } \\
\text { ISSN 1662-0631 } \\
\text { www.karger.com/crg }\end{array}$ \\
\hline
\end{tabular}

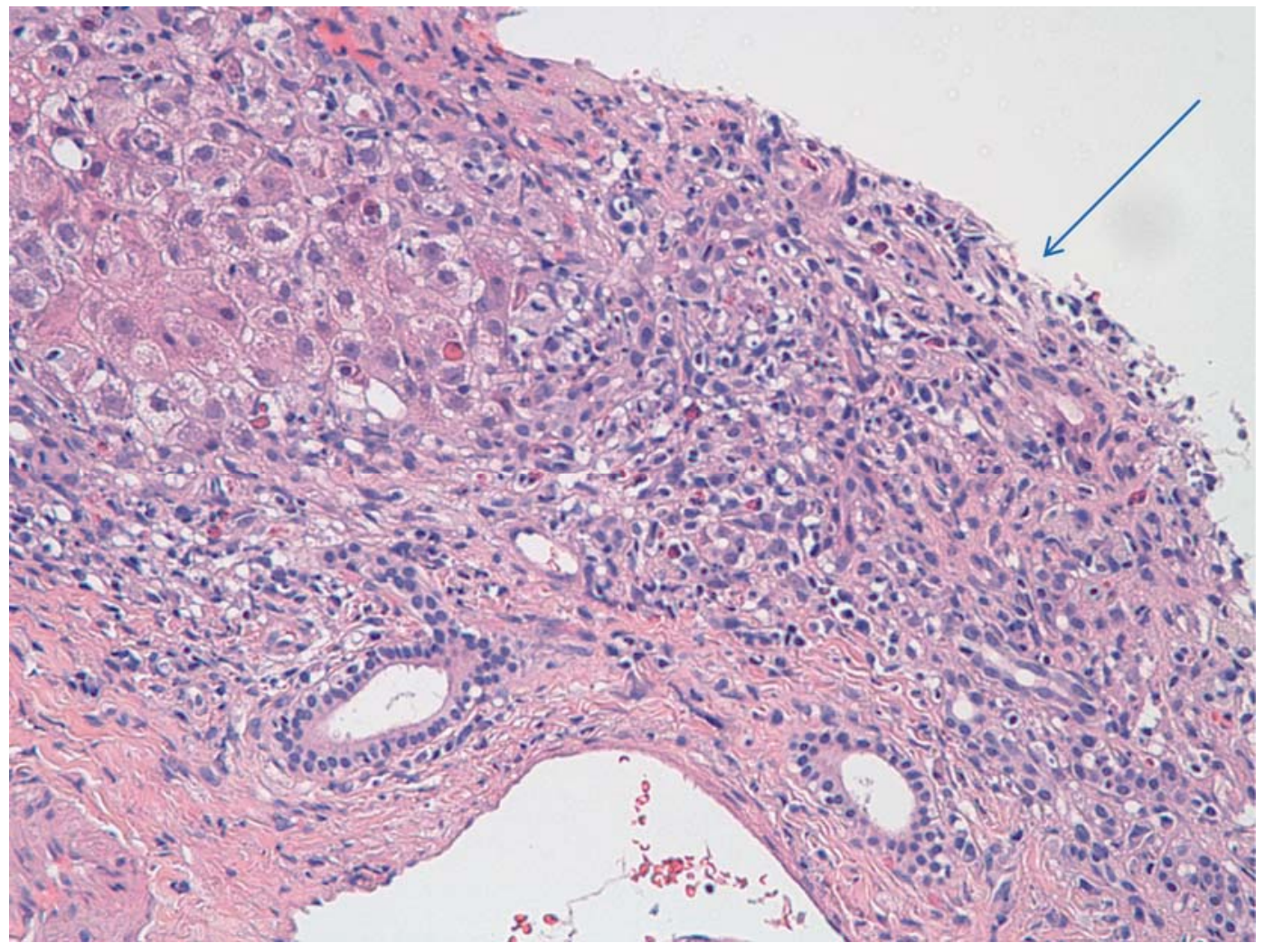

Fig. 1. Arrow: interface hepatitis. Note the lymphocytic infiltrate that extends from the portal tract into the liver lobule. 


\begin{tabular}{r|l|l|l}
$\begin{array}{r}\text { Case Reports in } \\
\text { Gastruanterology }\end{array}$ & $\begin{array}{l}\text { Case Rep Gastroenterol 2010;4:502-509 } \\
\text { DOl: 10.1159/000322693 }\end{array}$ & $\begin{array}{l}\text { Published online: } \\
\text { November 23, 2010 }\end{array}$ & $\begin{array}{l}\text { O 2010 S. Karger AG, Basel } \\
\text { ISSN 1662-0631 } \\
\text { www.karger.com/crg }\end{array}$ \\
\hline
\end{tabular}

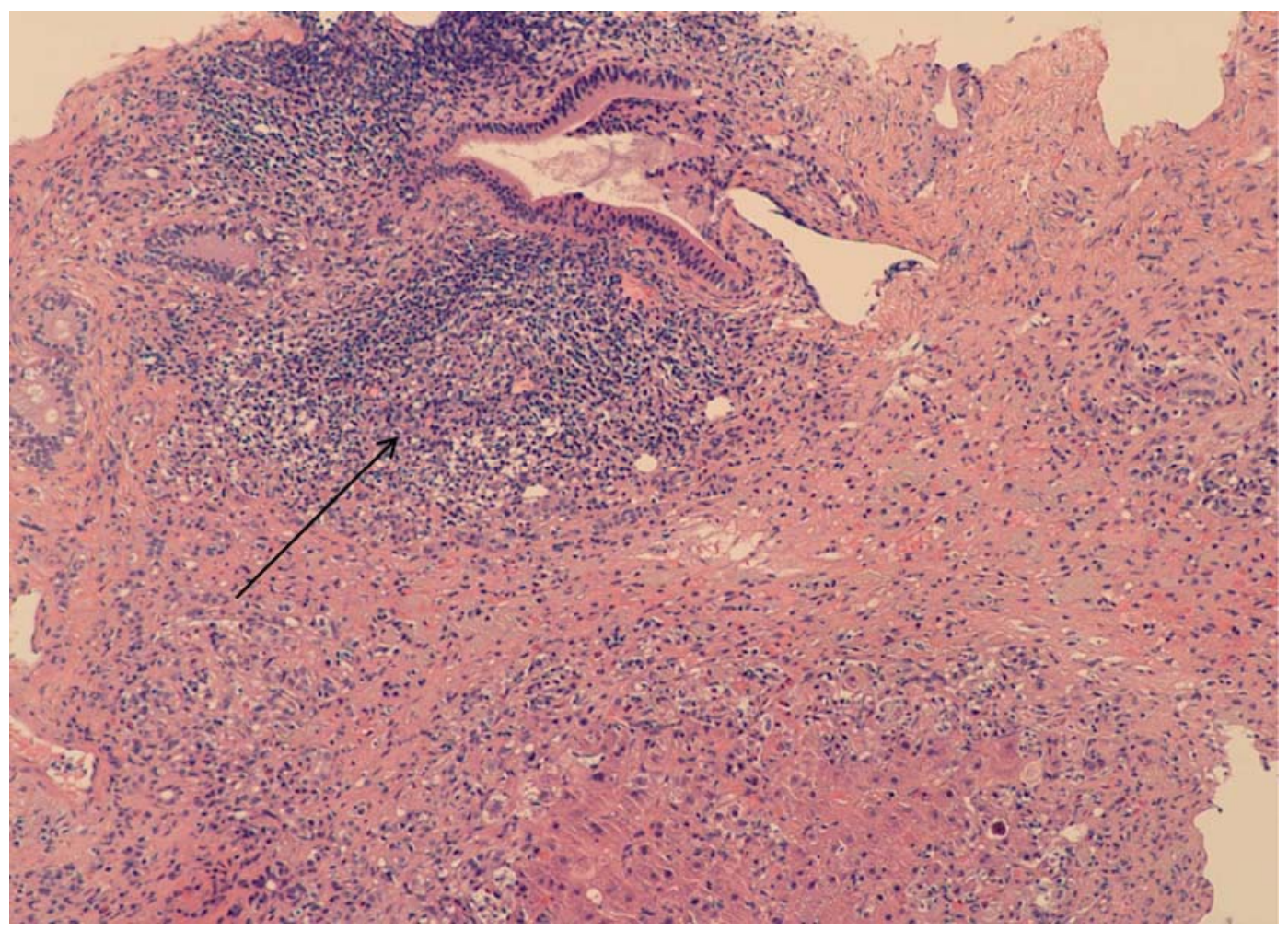

Fig. 2. Arrow: expanded portal inflammation with lymphocytic aggregate.

\section{References}

1 Waldenstrom J: The diagnostic importance of ACTH. Acta Endocrinol (Copenh) 1950;5:235-242.

2 Manns MP, Vogel A: Autoimmune hepatitis, from mechanisms to therapy. Hepatology 2006;43(2 suppl 1): S132-S144.

-3 Krawitt EL: Autoimmune hepatitis. N Engl J Med 2006;354:54-66.

-4 Murray-Lyon IM, Stern RB, Williams R: Controlled trial of prednisone and azathioprine in active chronic hepatitis. Lancet 1973;i:735-737.

5 Schalm SW, Ammon HV, Summerskill WH: Failure of customary treatment in chronic active liver disease: causes and management. Ann Clin Res 1976;8:221-227.

6 Vergani D, Choudhuri K, Bogdanos DP, Mieli-Vergani G: Pathogenesis of autoimmune hepatitis. Clin Liver Dis 2002;6:727-737.

7 Ngu JH, Bechly K, Chapman BA, Burt MJ, Barclay ML, Gearry RB, Stedman CA: Population-based epidemiology study of autoimmune hepatitis: a disease of older women? J Gastroenterol Hepatol 2010;25:1681-1686.

8 Alvarez F, Berg PA, Bianchi RB, et al: International autoimmune hepatitis group report: review of criteria for diagnosis of autoimmune hepatitis. J Hepatol 1999;31:929-938.

9 Czaja AJ: Diverse manifestations and evolving treatments of autoimmune hepatitis. Miverna Gastroenterol Dietol 2005;51:313-333.

10 Dienes HP, Popper H, Manns M, Baumann W, Thoenes W, Meyer Zum Buschenfelde KH: Histological features in autoimmune hepatitis. Z Gastroenterol 1989;27:325-330.

11 Vergani D, Alvarez F, Bianchi RB, et al: Liver autoimmune serology: a consensus statement from the committee for autoimmune serology of the International Autoimmune Hepatitis Group. J Hepatol 2004;41:677-683. 
12 Czaja AJ, Manns MP: The validity and importance of subtypes in autoimmune hepatitis: a point of view. Am J Gastroenterol 1995;90:1206-1211.

13 Homberg JC, Abuaf N, Bernard O, et al: Chronic active hepatitis associated with anti liver/kidney microsome type 1: a second type of 'autoimmune' hepatitis. Hepatology 1987;7:1333-1339.

14 Summerskill WHJ, Korman MG, Ammon HV, Baggenstoss AH: Prednisone for chronic active liver disease: dose titration, standard dose and combination with azathioprine compound. Gut 1975;16:876-883.

15 Czaja AJ: Treatment strategies in autoimmune hepatitis. Clin Liver Dis 2002;6:799-824.

16 Cooper N, Arnold DM: The effect of rituximab on humoral and cell mediated immunity and infection in the treatment of autoimmune diseases. Br J Haematol 2010;149:3-13.

17 Ayata G, Gordon FD, Lewis WD, et al: Liver transplantation for autoimmune hepatitis: a long-term pathologic study. Hepatology 2000;32:185-192. 